\title{
The Course of Renal Function After Radical Cystectomy with Ileal Conduit Diversion for Bladder Cancer
}

\author{
Mesane Kanserinde Radikal Sistektomi ve Illeal Kondüit Diversiyon Sonrası Böbrek \\ Fonksiyonlarının Seyri
}

\author{
(1) Cevahir Özer, (1) Mehmet Reşit Gören, (1) Tulga Eğilmez, (1) Ferhat Kılınç, (1) Sezgin Güvel \\ Başkent University Faculty of Medicine, Department of Urology, Adana, Turkiye
}

\section{What's known on the subject? and What does the study add?}

Renal function deterioration is one of the important adverse events related to radical cystectomy with ileal conduit diversion. However, most of the previous studies have evaluated change in renal function using serum creatinine values. In the present study, we retrospectively analyzed the yearly changes in the renal function assessed by the estimated glomerular filtration rate, more reliable parameter, in order to identify potentially modifiable risk factors associated with worsening of the renal function.

\begin{abstract}
Objective: We evaluated the course of the renal function and potential risk factors for renal deterioration in patients who had undergone radical cystectomy with ileal conduit diversion.

Materials and Methods: A retrospective study evaluated 121 patients, including 114 male and 7 female who underwent radical cystectomy with ileal conduit diversion. Estimated glomerular filtration rate (eGFR) was calculated and postoperative changes in renal function were reviewed. The clinical variables influencing renal function were evaluated.

Results: The median follow-up period was 35.6 months (range, 12.2 to 139.6 months). The mean eGFR was $78.37 \pm 27.58 \mathrm{~mL} / \mathrm{min} / 1.73 \mathrm{~m} \mathrm{~m}^{2}$ before surgery and $90.14 \pm 29.68 \mathrm{~mL} / \mathrm{min} / 1.73 \mathrm{~m}^{2}$ at 5 years postoperatively. The comparison of preoperative eGFR and the last follow-up eGFR showed the no statistically significant difference $(p=0.195)$. Statistical analysis showed that development of postoperative urinary tract obstruction and postoperative urinary tract infection were significant adverse factors ( $p=0.008, p=0.026$, respectively).

Conclusion: Thirty two patients (53.3\%) developed renal deterioration during the follow-up period. Development of urinary tract obstruction and urinary tract infection in the postoperative period were found to be significant adverse factors affecting renal function.
\end{abstract}

Keywords: Renal insufficiency, Urinary bladder neoplasms, Cystectomy, Urinary diversion

Öz

Amaç: Bu çalışmada mesane kanseri nedeniyle radikal sistektomi ve ileal kondüit diversiyon uygulanan hastalarda böbrek fonksiyonlarındaki değişiklik ve böbrek fonksiyon kaybı için potansiyel risk faktörleri değerlendirildi.

Gereç ve Yöntem: Retrospektif çalışmada radikal sistektomi ve ileal kondüit diversiyon yapılan 114 erkek ve 7 kadın, 121 hasta değerlendirildi. Tahmini glomerüler filtrasyon hızı (eGFR) hesaplandı ve postoperatif böbrek fonksiyon değişiklikleri gözden geçirildi. Böbrek fonksiyonlarını etkileyen klinik değişkenler değerlendirildi.

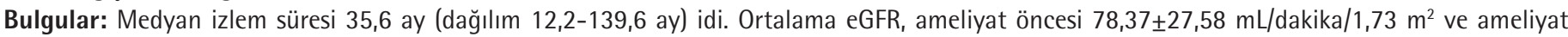
sonrası 5. yılda 90,14 $29,68 \mathrm{~mL} /$ dakika/1,73 $\mathrm{m}^{2}$ idi. Ameliyat öncesi eGFR ile son takipteki eGFR k arşılaştırması istatistiksel olarak anlamlı bir fark göstermedi $(p=1,95)$. İstatistiksel analiz postoperatif üriner sistem tıkanıklığı gelişiminin ve postoperatif üriner sistem enfeksiyonunun anlamlı olumsuz faktörler olduğunu gösterdi (sırası ile $p=0,008, p=0,026)$.

Sonuç: İzlem süreci boyunca, 32 hastanın $(\% 53,3)$ böbrek fonksiyonlarında azalma görüldü. Postoperatif üriner sistem tıkanıklığının böbrek fonksiyonlarını etkileyen önemli bir olumsuz faktör olduğu bulundu.

Anahtar Kelimeler: Böbrek yetmezliği, İdrar kesesi tümörleri, Sistektomi, Üriner diversiyon

Correspondence: Cevahir Özer MD, Başkent University Faculty of Medicine, Department of Urology, Adana, Turkiye

E-mail: mdcevahir@yahoo.com ORCID-ID: orcid.org/0000-0001-6037-7991

Received: 20.06.2018 Accepted: 21.08.2018

Cite this article as: Özer C, Gören MR, Eğilmez T, Kılınç F, Güvel S. The Course of Renal Function After Radical Cystectomy with lleal Conduit Diversion for Bladder Cancer. J Urol Surg 2019;6(1):21-26.

๑Copyright 2019 by the Association of Urological Surgery / Journal of Urological Surgery published by Galenos Publishing House. 


\section{Introduction}

Radical cystectomy (RC) and urinary diversion are the optimal treatment for muscle-invasive and high-grade non-muscleinvasive bladder cancer $(1,2)$. lleal conduit diversion (ICD) and orthotopic bladder substitution (BS) are two most frequently used urinary diversions after RC (3). Although BS has recently become more popular for urinary diversion, ICD is still believed to be appropriate for urinary diversion in most patients because of its relative simplicity, acceptable complication rate and satisfactory postoperative quality of life (4).

Deterioration in renal function is one of the most important adverse events related to RC and urinary diversion. Several studies have reported a high incidence of renal impairment in ICD patients. However, most of the previous studies have evaluated renal function using serum creatinine values, whereas estimated glomerular filtration rate (eGFR), in addition to serum creatinine, is a more accurate parameter for the measurement of renal function because it takes into account other relevant factors such as age, race and gender (5).

In the present study, we retrospectively analyzed the year-byyear changes in the renal function assessed by eGFR in order to identify potentially modifiable risk factors associated with worsening of the renal function in patients with primary bladder cancer who underwent RC with ICD.

\section{Materials and Methods}

A total of 121 (114 male and 7 female) patients, who had undergone RC with ICD for primary bladder cancer between March 2001 and July 2017, were identified. In this period, patients with RC and BS for bladder cancer were not included in the study because there were only 2 patients. The patient's desire and the surgeon's preference are major determinants for choice of urinary diversion methods. Cases of non-primary bladder cancer (direct extension of adenocarcinoma of the rectum in 1 patient), non-urothelial bladder cancers (carcinosarcoma in 1 patient and fibrosarcoma in 1 patient) and non-malignant bladder conditions (emphysematous cystitis in 1 patient and eosinophilic cystitis in 1 patient) were excluded. All data were obtained in accordance with the privacy protection policy of our institution. This study was approved by Başkent University Institutional Review Board (project no: KA16/16) and was supported by Başkent University Research Fund.

All patients underwent RC using standard techniques through the open approach. For urinary diversion, an ileal segment 15$20 \mathrm{~cm}$ long was isolated approximately $25 \mathrm{~cm}$ proximal to the ileocecal valve. The ureters were split and anastomosed to the proximal end of the ileum using the Wallace technique (6).
The primary outcome measure of this study was eGFR. Changes in renal function were examined using eGFR. eGFR was calculated using the modification of diet in renal disease (MDRD) equation: GFR $\left(\mathrm{mL} / \mathrm{min}\right.$ per $\left.1.73 \mathrm{~m}^{2}\right)=186 \times($ serum creatinine, $\mathrm{mg} / \mathrm{dL}$ )-1.154 $x$ (age) $-0.203 \times(0.742$ if female) $(7,8)$. Renal deterioration was defined as a reduction in the eGFR $>1 \mathrm{~mL} / \mathrm{min} / 1.73 \mathrm{~m}^{2}$ annually after RC. This definition, consistent with previous studies, is based on the fact that physiologic age-related GFR decreases 1 $\mathrm{mL} / \mathrm{min} / 1.73 \mathrm{~m}^{2}$ per year $(9,10)$.

Evaluated clinical variables that might influence renal function included age, gender, pathological tumor-node-metastasis stage, a prior history of hypertension or diabetes mellitus and renal function status, American Society of Anesthesiologists class risk, anatomical or functional solitary kidney, presence of preoperative urinary tract dilatation, postoperative febrile urinary tract infection, development of postoperative urinary tract obstruction, and presence of systemic chemotherapy. Patients with systolic blood pressure $>140 \mathrm{mmHg}$ and/or diastolic blood pressure $>90 \mathrm{mmHg}$ were regarded as hypertensive, patients with diabetes mellitus were defined as those who met the relevant diagnostic criteria and required glycemic control. Febrile urinary tract infection was defined as a febrile episode $\left(>38{ }^{\circ} \mathrm{C}\right.$ axillary) with a positive urine culture (bacteriuria of $>105 / \mathrm{mL}$ colony-forming units) in the absence of another indication for the cause of fever (1). Dilation encountered during upper tract imaging in patients with or without documentation of ureteroenteric or stomal obstruction was accepted as urinary tract obstruction (2). Solitary functioning kidney was defined as the presence of a contralateral non-functional kidney (uptake $<10 \%$ in dimercaptosuccinic acid scan) (11). The renal function status of patients was determined according to the Kidney Disease Outcomes Quality Initiative (KDOOI) guidelines. KDOQI guidelines stratify chronic kidney disease (CKD) into five stages according to eGFR level (Table 1) (12).

\section{Statistical Analysis}

Statistical analyses were performed using the statistical package SPSS version 24.0 (SPSS Inc., Chicago, IL, USA). For each continuous variable, normality was checked by the Kolmogorov-

Table 1. Stages of chronic kidney disease

\begin{tabular}{lll}
\hline Stage & Description & $\begin{array}{l}\text { GFR }(\mathbf{m L} / \\
\left.\text { min } / \mathbf{1 . 7 3 ~} \mathbf{~ m}^{2}\right)\end{array}$ \\
\hline 1 & Kidney damage with normal or $\uparrow$ GFR & $\geq 90$ \\
\hline 2 & Kidney damage with mild $\downarrow$ GFR & $60-89$ \\
\hline 3 & Moderate $\downarrow$ GFR & $30-59$ \\
\hline 4 & Severe $\downarrow$ GFR & $15-29$ \\
\hline 5 & Kidney failure & $<15$ or dialysis \\
\hline GFR: Glomerular filtration rate & \\
\hline
\end{tabular}


Smirnov test, Shapiro-Wilk test and histograms. The categorical variables between the groups were analyzed using a chi-square test or Fisher's exact test. A p value of less than 0.05 was considered statistically significant.

\section{Results}

The mean age of the patients was $62.03 \pm 7.37$ years. The median follow-up period after RC with ICD for patients alive at the last visit was 35.6 months (range, 12.2 to 139.6 months). Table 2 summarizes the characteristics of the 121 patients included in this study. The overall survival rate was $43.2 \%(35 / 81)$ at 5 years. Forty patients who were lost-to-follow-up were excluded from the overall survival assessment.

Figure 1 shows the median eGFR course. A decrease in eGFR was documented in 32 of 60 patients (53.3\%) who could be followed at least one year. At 5 years postoperatively, the median eGFR

Table 2. Patient characteristics

\begin{tabular}{ll}
\hline Characteristic & $\mathbf{n}(\%)$ \\
\hline Gender & $7(5.8)$ \\
\hline Female & $114(94.2)$ \\
Male & \\
\hline Comorbidity & $27(22.3)$ \\
\hline Hypertension & $16(13.2)$ \\
Diabetes mellitus & $35(28.9)$ \\
Preoperative hydronephrosis & $14(11.6)$ \\
Solitary kidney & \\
\hline pTNM stage & $7(5.8)$ \\
\hline Tcis & $1(0.8)$ \\
Ta & $13(10.7)$ \\
T0 & $10(8.3)$ \\
T1 & $28(23.1)$ \\
T2 & $28(23.1)$ \\
T4 & $34(28.1)$ \\
\hline CKD stage & \\
\hline 1 & $71(33.9)$ \\
2 & $48(39.7)$ \\
3 & $27(22.3)$ \\
\hline & $2(1.7)$ \\
\hline ASA class & $3(2.5)$ \\
\hline 1 & $39(32.2)$ \\
\hline
\end{tabular}

pTNM: Pathological tumor-node-metastasis, CKD: Chronic kidney disease, ASA: American Society of Anesthesiologists, Tcis: Carcinoma in situ had increased from $77.43 \mathrm{~mL} / \mathrm{min} / 1.73 \mathrm{~m}^{2}$ to $79.2 \mathrm{~mL} / \mathrm{min} / 1.73$ $\mathrm{m}^{2}$. The change in eGFR was statistically insignificant.

The patients were evaluated with the CKD classification; in 14 (23.3\%) patients, CKD stage was found to be worsened (Table 3). Moreover, preoperative and postoperative CKD stage was similar $(p=0.80)$.

Statistical analysis showed that the development of postoperative urinary tract obstruction and postoperative urinary tract infection were significant adverse factors for

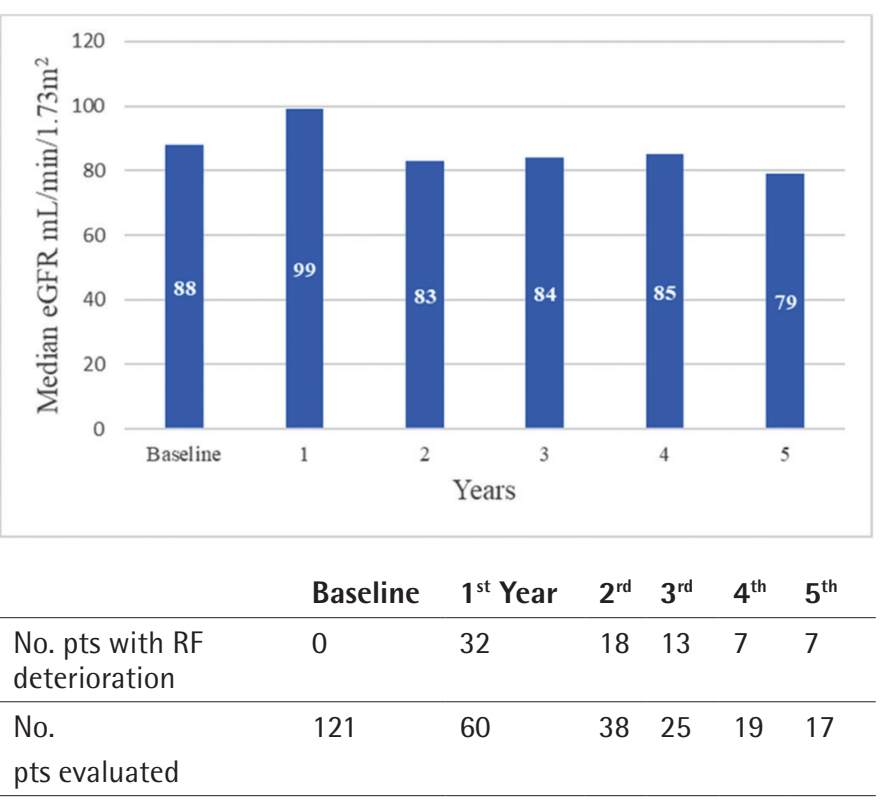

Figure 1. Change in median estimated glomerular filtration rate after radical cystectomy with ileal conduit diversion across the postoperative period

eGFR: Estimated glomerular filtration rate, RF: Renal function, Pts: Patients

Table 3. Postoperative course of renal function according to chronic kidney disease stage

\begin{tabular}{|c|c|c|c|}
\hline CKD stage & $\begin{array}{l}\text { Preoperative } \\
\text { n (\%) }\end{array}$ & $\begin{array}{l}\text { Postop alteration } \\
\text { of renal function } \\
\text { (n) }\end{array}$ & $\begin{array}{l}\text { Last follow-up } \\
\text { n (\%) }\end{array}$ \\
\hline \multirow[t]{3}{*}{1} & $41(33.9)$ & Worsening: 7 & $16(26.7)$ \\
\hline & & To stage 2: 5 & \\
\hline & & To stage $3: 2$ & \\
\hline \multirow[t]{5}{*}{2} & 48 (39.7) & Worsening: 7 & $30(50)$ \\
\hline & & To stage $3: 6$ & \\
\hline & & To stage $4: 1$ & \\
\hline & & Improvement: 1 & \\
\hline & & To stage $1: 1$ & \\
\hline \multirow[t]{3}{*}{3} & $27(22.3)$ & Improvement: 4 & $13(21.7)$ \\
\hline & & To stage $1: 1$ & \\
\hline & & To stage $2: 3$ & \\
\hline 4 & $2(1.7)$ & - & $1(1.6)$ \\
\hline 5 & $3(2.5)$ & - & - \\
\hline CKD: Chronic & y disease & & \\
\hline
\end{tabular}


deterioration of kidney function. The other risk factors did not affect the renal function outcomes (Table 4).

Of the $21(17.3 \%)$ patients with postoperative urinary tract dilatation, 8 (38.1\%) had ureteroileal stricture, 4 (19\%) had ureteral recurrence, $1(4.8 \%)$ ureteral compression secondary to a metastatic lymph node, and 1 (4.8\%) had ureteral stone. For 7 patients (33.3\%), no cause for the upper urinary tract dilatation was found. The location and approach towards urinary tract dilatation are summarized in Table 5.

\section{Discussion}

Renal function is one of the most important points to be assessed after RC and urinary diversion and, protection of the renal function is an essential goal after $\mathrm{RC}$ and urinary diversion.

In the literature, there is no consensus on how to assess renal function after RC. GFR is widely accepted as the best marker of renal function (13). Although urinary inulin clearance is considered the gold standard measurement for GFR, the use of inulin is expensive, invasive, complex and has limited use in routine clinical settings $(14,15,16)$. The creatinine-based eGFR equations are alternative non-invasive methods for easily assessing renal function because of their simplicity $(16,17,18)$.

Table 4. Analysis of clinicopathological variables and complications associated with renal function deterioration

\begin{tabular}{l|l}
\hline & $\begin{array}{l}\text { Renal function } \\
\text { outcome p value }\end{array}$ \\
\hline pTNM stage & 0.453 \\
\hline Preoperative urinary tract dilatation & 0.397 \\
\hline Chemotherapy & 0.271 \\
\hline Postoperative urinary tract dilatation & 0.008 \\
\hline Postoperative urinary tract infection & 0.026 \\
\hline Diabetes mellitus & 0.109 \\
\hline Hypertension & 0.312 \\
\hline Solitary kidney & 1 \\
\hline ASA & 0.715 \\
\hline $\begin{array}{l}\text { pTNM: Pathological tumor-node-metastasis, ASA: American Society of } \\
\text { Anesthesiologists }\end{array}$
\end{tabular}

The MDRD equation is one of these equations and has gained widespread acceptance (17). Serum creatinine measurement, intravenous urography and radioisotope renography also have been used to evaluate renal function $(1,3,16,19,20,21)$. Serum creatinine is the most commonly used biochemical marker of renal function, but is not a sensitive marker to assess deterioration of renal function $(3,18,22)$. This marker is affected by numerous factors such as age, gender, race, hydration level and muscle mass $(2,23)$.

Definition of renal deterioration is also unclear. When we look at the small number of studies available in the literature which have used eGFR, we see that there are different definitions such as CKD stage changes, 25\% decline in eGFR from baseline and a decrease in eGFR by $>1 \mathrm{~mL} / \mathrm{min} / 1.73 \mathrm{~m}^{2}$ per year $(1,2,3,24)$. In this study, we used the eGFR and annual change in eGFR.

Our study shows that $53.3 \%$ of patients who underwent RC with ICD experienced renal deterioration during the follow-up period. However, the changes in renal function were not statistically significant. In a study by Osawa et al. (1), the renal deterioration rate was $29 \%$ in 25 patients who underwent RC with ICD for bladder cancer. In the report by Osawa et al. (1), the definition of renal deterioration was described as a $>25 \%$ decrease in eGFR compared to the preoperative renal function. However, in our study, we described renal deterioration as any decrease from the expected GFR. Thus, this difference may explain why this ratio is lower than ours ( $29 \%$ vs $53.3 \%$ ). Jin et al. (3) reported that $36 \%$ of 50 patients (42 of them had bladder cancer), who underwent $\mathrm{RC}$ with ICD, experienced renal function decline in a followup period of more than 10 years. In this study, deterioration in renal function was defined as a decrease in GFR by $>10 \mathrm{~mL} /$ $\mathrm{min} / 1.73 \mathrm{~m}^{2}$ in 10 years (3). In another study with a followup of 10 years, the rate of renal deterioration in 73 patients, who underwent RC with ICD for bladder cancer, was reported as $71 \%$. This rate has been reported as $26 \%$ in the first year of the follow-up and 54\% in the fifth year of follow-up (2). In a study by Rouanne et al. (10), these rates were reported as $39.3 \%$ and $20.3 \%$, respectively. In our study, renal function deterioration was seen in 53.3\% of patients in the first year and $41.1 \%$ of patients in the fifth year.

Table 5. Location and management of urinary tract dilatation

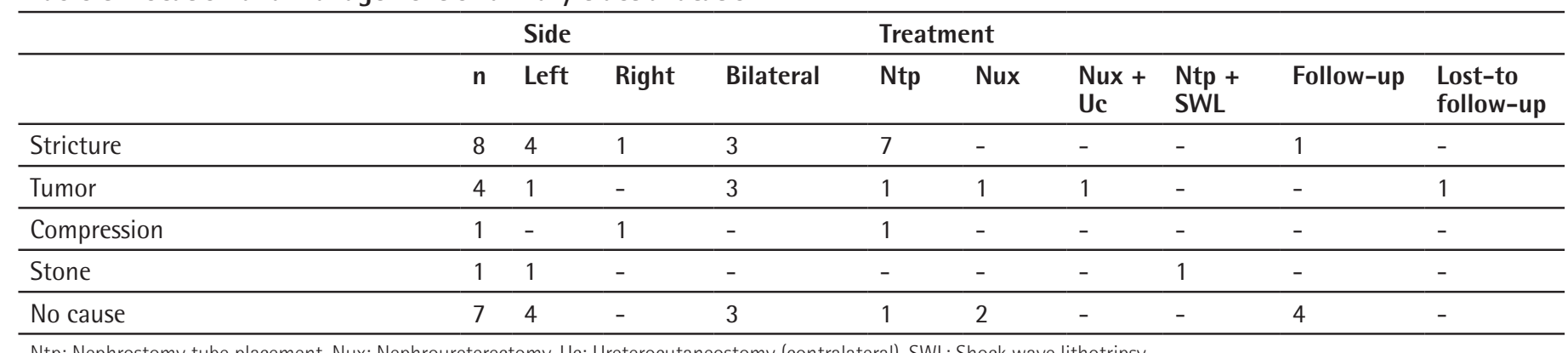

Ntp: Nephrostomy tube placement, Nux: Nephroureterectomy, Uc: Ureterocutaneostomy (contralateral), SWL: Shock wave lithotripsy 
Jin et al. (3) reported that 13 of 50 patients (26\%) developed stage 3-5 CKD in more than 10 years after RC with ICD for bladder cancer. In our study, 9 patients (15\%) developed stage 3-5 CKD during the follow-up period. Although we have detected a worsening in the CKD stage in 23.3\% of patients during the follow-up period, this was not statistically significant. Considering that the median follow-up in our study was 35.6 months, a longer follow-up period might reveal if worsening of CKD is time-related.

Urinary diversion-related and -unrelated potential factors which may affect renal function deterioration include age, gender, a prior history of hypertension or diabetes mellitus, preoperative renal function, presence of preoperative urinary tract dilatation, postoperative febrile urinary tract infection, development of postoperative urinary tract obstruction, and systemic chemotherapy $(1,2,3,24,25,26,27)$. Although the preoperative and postoperative eGFR values were statistically insignificant, the development of postoperative urinary tract obstruction and postoperative urinary tract infection were the only significant risk factors for renal deterioration.

The pathophysiology of urinary obstruction resulting from inflammatory process, apoptosis and fibrosis is highly complex (28). The effect of urinary obstruction on renal function depends on numerous factors, such as the duration (acute or chronic), side (unilateral or bilateral) and degree (partial or complete) of dilatation, contralateral kidney function, age, compliance of ureter and renal pelvis, pyelolymphatic backflow, presence of accompanying urinary tract infection and use of nephrotoxic agents and medications (29). The relief of obstruction for the improvement or the stabilization of the renal function is almost universally accepted. However, in practice, it may not be easy to separate the obstructive dilatation from the non-obstructive (30).

Ureteroileal anastomosis technique is controversial. Selection of anastomosis technique is generally based on surgeon's preference. Bricker and Wallace remain the two most common surgical techniques of ureteroenteric anastomosis for ileal conduit (31). These techniques are proven to be reliable and safe. In terms of ureteroileal stricture, both techniques provide similar and acceptable rates $(31,32)$. We cannot make a comparison because only Wallace technique was used in our study.

\section{Study Limitations}

The limitations of this study include its retrospective and nonrandomized design and small sample size. The lack of a control group was a limiting factor for assessing the effect of RC with ICD on the renal function.

\section{Conclusion}

In the current study, statistically insignificant reduction of renal function developed in 32 patients (53.3\%) during the follow-up period after RC with ICD. We identified development of postoperative urinary tract obstruction and postoperative urinary tract infection as risk factors for deterioration of renal function. Recognition of these potential risk factors and early intervention for urinary tract obstruction and prevention of urinary tract infection may help preserve the postoperative renal function in patients undergoing $\mathrm{RC}$ with ICD.

\section{Ethics}

Ethics Committee Approval: This study was approved by Başkent University Institutional Review Board (project no: KA16/16) and was supported by Başkent University Research Fund.

Informed Consent: Retrospective study.

Peer-review: Externally peer-reviewed.

\section{Authorship Contributions}

Surgical and Medical Practices: C.Ö., M.R.G., T.E., F.K., S.G., Concept: C.O., M.R.G., Design: C.O., M.R.G., Data Collection or Processing: C.O., Analysis or Interpretation: C.O., M.R.G., Literature Search: C.O., Writing: C.O., M.R.G., T.E.

Conflict of Interest: No conflict of interest was declared by the authors.

Financial Disclosure: The authors declared that this study received no financial support.

\section{References}

1. Osawa T, Shinohara N, Maruyama S, Oba K, Abe T, Maru S, Takada N, Sazawa A, Nonomura K. Long-term renal function outcomes in bladder cancer after radical cystectomy. Urol J 2013;10:784-789.

2. Eisenberg MS, Thompson RH, Frank I, Kim SP, Cotter KJ, Tollefson MK, Kaushik D, Thapa $P$, Tarrell $R$, Boorjian SA. Long-term renal function outcomes after radical cystectomy. J Urol 2014;191:619-625.

3. Jin XD, Roethlisberger $S$, Burkhard FC, Birkhaeuser F, Thoeny HC, Studer UE. Long-term renal function after urinary diversion by ileal conduit or orthotopic ileal bladder substitution. Eur Urol 2012;61:491-497.

4. Liu L, Chen M, Li Y, Wang L, Qi F, Dun J, Chen J, Zu X, Qi L. Technique selection of bricker or wallace ureteroileal anastomosis in ileal conduit urinary diversion: a strategy based on patient characteristics. Ann Surg Oncol 2014;21:2808-2812.

5. Nishikawa M, Miyake $H$, Yamashita M, Inoue TA, Fujisawa M. Long-term changes in renal function outcomes following radical cystectomy and urinary diversion. Int J Clin Oncol 2014;19:1105-1111.

6. Wallace DM. Ureteric diversion using a conduit: a simplified technique. Br J Urol 1966;38:522-527.

7. Levey AS, Bosch JP, Lewis JB, Greene T, Rogers N, Roth D. A more accurate method to estimate glomerular filtration rate from serum creatinine: a new prediction equation. Modification of Diet in Renal Disease Study Group. Ann Intern Med 1999;130:461-470.

8. Levey AS, Coresh J, Greene T, Stevens LA, Zhang YL, Hendriksen S, Kusek JW, Van Lente F. Using standardized serum creatinine values in the modification of diet in renal disease study equation for estimating glomerular filtration rate. Ann Intern Med 2006;145:247-254. 
9. Thomas C, Thomas L. Renal failure--measuring the glomerular filtration rate. Dtsch Arztebl Int. 2009;106:849-854.

10. Rouanne M, Perreaud A, Letang N, Yonneau L, Neuzillet Y, Herve JM, Botto $H$, Lebret $T$. Trends in renal function after radical cystectomy and ileal conduit diversion: new insights regarding estimated glomerular filtration rate variations. Clin Genitourin Cancer 2015;13:139-144.

11. Hosseini Sharifi SH, Keihani S, Nabavizadeh B, Kajbafzadeh AM. Endoscopic correction of vesicoureteral reflux in children with solitary functioning kidney: insertion of a double-J stent to avoid transient ureteral obstruction. Int Urol Nephrol 2016;48:313-318.

12. National Kidney F. K/DOOI clinical practice guidelines for chronic kidney disease: evaluation, classification, and stratification. Am J Kidney Dis 2002;39:1-266.

13. Filler G, Yasin A, Medeiros M. Methods of assessing renal function. Pediatr Nephrol 2014;29:183-192.

14. Traynor J, Mactier R, Geddes CC, Fox JG. How to measure renal function in clinical practice. BMJ 2006;333:733-737.

15. Sandilands EA, Dhaun N, Dear JW, Webb DJ. Measurement of renal function in patients with chronic kidney disease. Br J Clin Pharmacol 2013;76:504-515.

16. Choi HY, Joo DJ, Song MK, Kim MS, Park HC, Kim YS, Kim BS. The Power of Renal Function Estimation Equations for Predicting Long-Term Kidney Graft Survival: A Retrospective Comparison of the Chronic Kidney Disease Epidemiology Collaboration and the Modification of Diet in Renal Disease Study Equations. Medicine (Baltimore) 2016;95:2682.

17. Selistre L, De Souza V, Cochat P, Antonello IC, Hadj-Aissa A, Ranchin B, Dolomanova O, Varennes A, Beyerle F, Bacchetta J, Dubourg L. GFR estimation in adolescents and young adults. J Am Soc Nephrol 2012;23:989-996.

18. Selistre L, Rabilloud M, Cochat $P$, de Souza V, Iwaz J, Lemoine $S$, Beyerle $F$, Poli-de-Figueiredo CE, Dubourg L. Comparison of the Schwartz and CKD-EPI Equations for Estimating Glomerular Filtration Rate in Children, Adolescents, and Adults: A Retrospective Cross-Sectional Study. PLoS Med 2016;13:1001979.

19. Lantz AG, Saltel ME, Cagiannos I. Renal and functional outcomes following cystectomy and neobladder reconstruction. Can Urol Assoc J 2010;4:328331.

20. Minervini R, Pagni R, Mariani C, Morelli A, Morelli G, Minervini A. Effects on renal function of obstructive and nonobstructive dilatation of the upper urinary tract in ileal neobladders with refluxing ureteroenteric anastomoses. Eur J Surg Oncol 2010;36:287-291.

21. Thoeny HC, Sonnenschein MJ, Madersbacher S, Vock P, Studer UE. Is ileal orthotopic bladder substitution with an afferent tubular segment detrimental to the upper urinary tract in the long term? J Urol 2002;168:2030-2034.

22. Kristjansson $A$, Mansson $W$. Renal function in the setting of urinary diversion. World J Urol 2004;22:172-177.

23. Levey $A S$, Stevens $L A$, Schmid $C H$, Zhang $Y L$, Castro AF, Feldman HI, Kusek JW, Eggers P, Van Lente F, Greene T, Coresh J, Ckd EPI. A new equation to estimate glomerular filtration rate. Ann Intern Med 2009;150:604-612.

24. Gershman B, Eisenberg MS, Thompson RH, Frank I, Kaushik D, Tarrell R, Thapa $\mathrm{P}$, Boorjian SA. Comparative impact of continent and incontinent urinary diversion on long-term renal function after radical cystectomy in patients with preoperative chronic kidney disease 2 and chronic kidney disease 3a. Int J Urol 2015;22:651-656.

25. Harraz AM, Mosbah A, El-Assmy A, Gad H, Shaaban AA. Renal function evaluation in patients undergoing orthotopic bladder substitution: a systematic review of literature. BJU Int 2014;114:484-495.

26. Hatakeyama $S$, Koie $T$, Narita $T$, Hosogoe $S$, Yamamoto $H_{\text {, Tobisawa }} Y_{\text {, }}$ Yoneyama T, Yoneyama T, Hashimoto Y, Ohyama C. Renal Function Outcomes and Risk Factors for Stage 3B Chronic Kidney Disease after Urinary Diversion in Patients with Muscle Invasive Bladder Cancer [corrected]. PLoS One 2016;11:0149544.

27. Gondo T, Ohno Y, Nakashima J, Hashimoto T, Nakagami $Y$, Tachibana M. Preoperative determinant of early postoperative renal function following radical cystectomy and intestinal urinary diversion. Int Urol Nephrol 2017:49:233-238.

28. Chevalier RL. Pathogenesis of renal injury in obstructive uropathy. Curr Opin Pediatr 2006;18:153-160.

29. Khalaf IM, Shokeir AA, El-Gyoushi FI, Amr HS, Amin MM. Recoverability of renal function after treatment of adult patients with unilateral obstructive uropathy and normal contralateral kidney: a prospective study. Urology 2004;64:664-668.

30. Shokeir AA. The diagnosis of upper urinary tract obstruction. BJU Int 1999:83:893-900.

31. Davis NF, Burke JP, McDermott TED, Flynn R, Manecksha RP, Thornhill JA. Bricker versus Wallace anastomosis: A meta-analysis of ureteroenteric stricture rates after ileal conduit urinary diversion. Can Urol Assoc J 2015;9:284-290.

32. Colombo R, Naspro R. Ileal Conduit as the Standard for Urinary Diversion After Radical Cystectomy for Bladder Cancer. Eur Urol 2010;9:736-744. 